\title{
Biodegradable magnesium implants: a potential scaffold for bone tumor patients
}

\author{
Rui $\mathrm{Zan}^{1 \dagger}$, Weiping Ji ${ }^{2 \dagger}$, Shuang Qiao ${ }^{1}$, Hongliu $\mathrm{Wu}^{1}$, Wenhui Wang ${ }^{1}$, Tianjiao $\mathrm{Ji}^{3}$, \\ Bangcheng Yang ${ }_{1^{*}}^{4}$ Shaoxiang Zhang ${ }^{5}$, Congfeng Luo ${ }^{2}$, Yang Song ${ }^{1^{*}}$, Jiahua $\mathrm{Ni}^{6^{*}}$ and \\ Xiaonong Zhang
}

\begin{abstract}
Relapse and metastasis of tumor may occur for osteosarcoma (OS) patients after clinical resection. Conventional metallic scaffolds provide sufficient mechanical support to the defected bone but fail to eradicate recurring tumors. Here we report that biodegradable magnesium (Mg) wirebased implant can inhibit OS growth. In brief, the $\mathrm{Mg}$ wires release $\mathrm{Mg}$ ions to activate the transport of zinc finger protein Snaill from cytoplasm to cell nucleus, which induces apoptosis and inhibits proliferation of OS cells through a parallel antitumor signaling pathway of miRNA-181d-5p/TIMP3 and miRNA-181c-5p/NLK downstream. Simultaneously, the hydrogen gas evolution from $\mathrm{Mg}$ wires eliminates intracellular excessive reactive oxygen species, by which the growth of bone tumor cells is suppressed. The subcutaneous tumor-bearing experiment of $\mathrm{OS}$ cells in nude mice further confirms that $\mathbf{M g}$ wires can effectively inhibit the growth of tumors and prolong the survival of tumor-bearing mice. In addition, $\mathrm{Mg}$ wires have no toxicity to normal cells and tissues. These results suggest that $\mathrm{Mg}$ implant is a potential anti-tumor scaffold for OS patients.
\end{abstract}

Keywords: magnesium wire, osteosarcoma inhibition, hydrogen evolution, Snail1, miRNA-181

\section{INTRODUCTION}

Osteosarcoma (OS) is a common malignant bone tumor derived from bone-forming mesenchymal cells in a premature state [1]. In the USA, about 3450 new cases of bone sarcoma are diagnosed in 2018 [2]. Clinically, OS is often treated by removing through surgery combined with additional chemotherapy [3]. Nevertheless, incomplete surgical resection of the tumor tissue induces the metastasis of tumor cells, and the 5-year survival rate of these tumor patients after operation is only $60 \%-70 \%$ [4]. A promising solution for the tumor disease is to refill the bone defects with an antitumor and regenerative scaffold, which provides additional mechanical support to the bone and simultaneously inhibits the recurring of bone tumors [5].

Among various candidate materials, $\mathrm{Mg}$ and its alloys have been employed to promote the regeneration of fractured bone or bone loss [6,7], due to their biodegradability, excellent biocompatibility, and mechanical robustness for bone rehabilitation [8-10]. Implantation of $\mathrm{Mg}$ scaffold is a promising solution for the treatment of OS due to the following reasons: (1) the released $\mathrm{Mg}^{2+}$ promotes proliferation of osteoblast in vitro and accelerates the repair of premature bone in vivo [11,12]; (2) degradation products of $\mathrm{Mg}$ exhibit anti-tumor properties in vitro [13], and these degradation products are welltolerated in vivo; (3) the in vivo degradation cycle of $\mathrm{Mg}$ can be tuned from six months to several years, which matches the long-term treatment cycle of OS [14-16]. Previous studies demonstrated that the degradation of $\mathrm{Mg}$ releases $\mathrm{Mg}(\mathrm{OH})_{2}$ and elevates the alkalinity of the cell culture medium [17], by which the tumor cells were killed

\footnotetext{
${ }^{1}$ State Key Laboratory of Metal Matrix Composites, School of Materials Science and Engineering, Shanghai Jiao Tong University, Shanghai 200240, China

${ }^{2}$ Department of Orthopedic Surgery, Shanghai Jiao Tong University Affiliated Sixth People's Hospital, Shanghai 200233, China

${ }^{3}$ Laboratory for Biomaterials and Drug Delivery, Department of Anesthesiology, Boston Children's Hospital, Harvard Medical School, Boston, Massachusetts 02115, USA

${ }^{4}$ Engineering Research Center in Biomaterials, Sichuan University, Chengdu 610064, China

${ }^{5}$ Suzhou Origin Medical Technology Co. Ltd., Suzhou 215513, China

${ }^{6}$ Department of Mechanical Engineering, Massachusetts Institute of Technology, Cambridge, Massachusetts 02139, USA

† These authors contributed equally to this work.

* Corresponding authors (emails: jiahuani@mit.edu (Ni J); nanosurface@sjtu.edu.cn (Song Y); xnzhang@sjtu.edu.cn (Zhang X))
} 
$[18,19]$. However, it remains unknown if the increased alkalinity can be maintained in vivo, where the $\mathrm{pH}$ buffer system in the body may dampen the antitumor effect.

In this work, we exploited high-purity $\mathrm{Mg}$ wires with a good mechanical property and stable degradation performance, which dramatically inhibit the growth of OS cells in vitro and in vivo through a unique pathway. Different from previous studies, we revealed the alkalinity-induced damage to tumor cells; instead, the antitumor effect of $\mathrm{Mg}$ ions or $\mathrm{H}_{2}$ was scrutinized separately. Our animal experiment also confirmed that implanted $\mathrm{Mg}$ wires successfully prolong the survival time and suppress the bone tumors in mice.

\section{EXPERIMENTAL SECTION}

\section{Material preparation and sterilization}

The as-casted $\mathrm{Mg}$ with a high purity of $99.98 \%$ was extruded to a rod and then pulled into a thin wire with a final diameter of $0.77 \mathrm{~mm}$ provided by Suzhou Origin Medical Technology Co. Ltd., China. The sample was ultrasonically cleaned with acetone (for $10 \mathrm{~min}$ ) and ethanol (for $15 \mathrm{~min}$ ) to reduce organic substances on the surface. Ultraviolet (UV) radiation was used for specimen sterilization for $20 \mathrm{~min}$ before corrosion and cell culture tests.

\section{Mechanical and in vitro corrosion tests}

The mechanical properties of $\mathrm{Mg}$ wires were tested and shown in Fig. 1. The corrosion test for high-purity $\mathrm{Mg}$ wires was carried out in the modified simulated body fluid (m-SBF) for two weeks. The ratio of the surface area of $\mathrm{Mg}$ to the volume of $\mathrm{m}-\mathrm{SBF}$ was maintained at $1 \mathrm{~cm}^{2} /$ $30 \mathrm{~mL}$. The hydrogen released from the $\mathrm{Mg}$ sample was dissolved in solution and tested by a dissolved hydrogen analyzer (ENH-1000, Truslex, Japan). Changes in the $\mathrm{pH}$ value of the $\mathrm{m}-\mathrm{SBF}$ were recorded during the immersion test. After 1, 4, 7, and 14 days, the concentration of $\mathrm{Mg}^{2+}$ released into $\mathrm{m}$-SBF was quantified with an inductively coupled plasma optical emission spectrometer (ICP-OES, ICAP 6300, Thermo Scientific, USA). The corroded samples were sequentially rinsed in a solution containing $180 \mathrm{~g} \mathrm{~L}^{-1} \mathrm{CrO}_{3}$ and $10 \mathrm{~g} \mathrm{~L}^{-1} \mathrm{AgNO}_{3}$, and distilled water to remove $\mathrm{Mg}(\mathrm{OH})_{2}$ adsorbed. The surface morphology of the $\mathrm{Mg}$ wire after the immersion test was observed using scanning electron microscopy (FE-SEM, Sirion 200, FEI, USA). The weight loss of $\mathrm{Mg}$ wire before and after the immersion test was calculated.

\section{Preparation of culture medium}

To test the effect of $\mathrm{Mg}^{2+}$ on the cell viability, the culture medium was supplemented with additional $\mathrm{Mg}^{2+}$ concentrations by adding magnesium chloride $\left(\mathrm{MgCl}_{2}\right)$. The osmolality of the medium was measured using a vapor pressure osmometer (Osmo210, YASH, UK). The final concentrations of $\mathrm{Mg}^{2+}$ were maintained at 5, 10, 20 and $40 \mathrm{mmol} \mathrm{L}^{-1}$.

To evaluate the effect of alkaline on the cell viability,

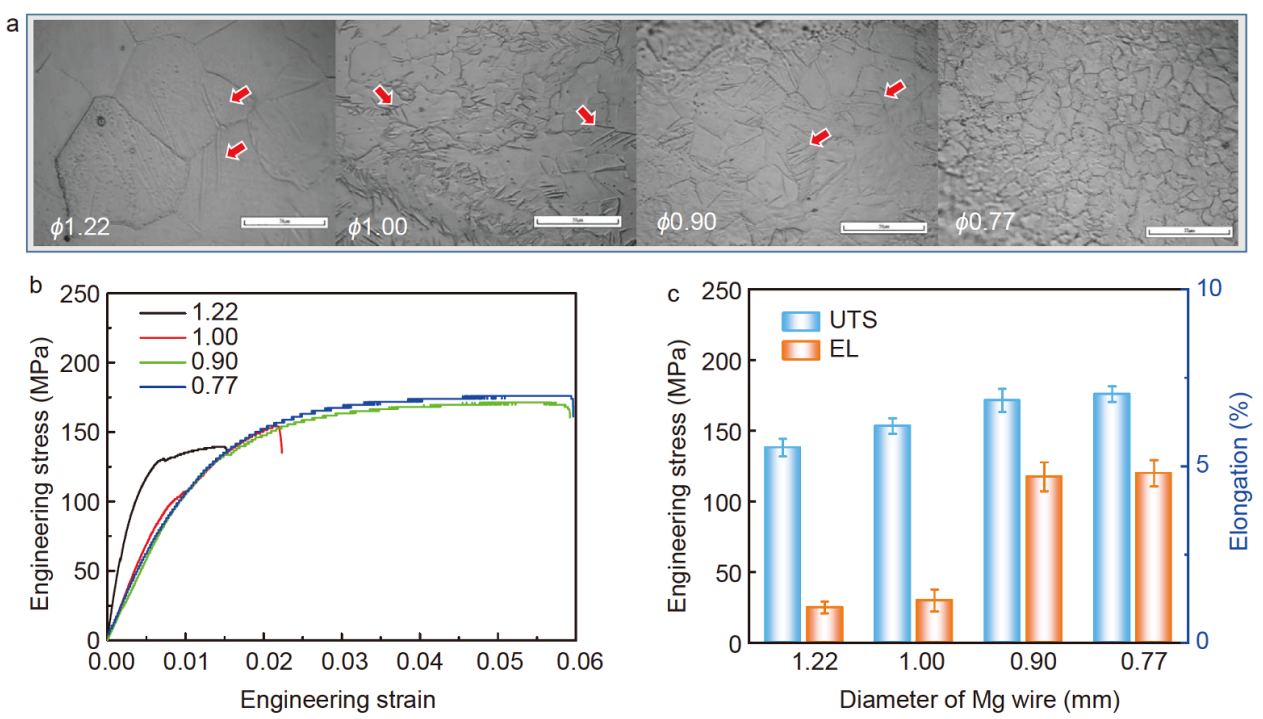

Figure 1 Microstructure characterization and mechanical properties of Mg wires with different diameters. (a) Metallographic images of Mg wires with different diameters. Scale bar: $50 \mu \mathrm{m}$. (b) Stress-strain curves, and (c) mechanical properties of Mg wires with different diameters, $n=3$. UTS: ultimate tensile strength; EL: elongation. 
the Minimum Essential Medium (MEM) and Roswell Park Memorial Institute (RPMI-1640) culture medium of tumor cells were adjusted with different $\mathrm{pH}$ values by a sterilized sodium hydroxide $(\mathrm{NaOH})$ solution. The final $\mathrm{pH}$ values of the media were adjusted to 7.4, 7.7 and 8.0.

\section{Setups for hydrogen exposure during cell culture}

$\mathrm{Mg}$ wires $(\Phi 0.26 \times 40 \mathrm{~mm})$ were laid into a 6-well microplate filled with $1 \mathrm{~mL}$ phosphate-buffered saline (PBS) in each well. Plate inserts fitting the 6-well microplates were coated with polycarbonate membrane and seeded with tumor cells. To control the level of hydrogen exposed to cells, a number of $\mathrm{Mg}$ wires (up to 4 pieces) were immersed into each well and labeled accordingly, e.g., a label of "MW2" denotes 2 pieces of Mg wires that were used for the cell test in each well.

\section{Cytotoxicity measurement of $\mathrm{Mg}$ wire and degradation products}

The human OS cells, MG63 and U2-OS, and normal human bone cells, C28/I2 cells, were seeded and cultured in 96-well plates. After overnight culture, the medium was replaced by (1) the complete medium with sterilized $\mathrm{Mg}$ wires $(\Phi 0.26 \times 5 \mathrm{~mm})$, or (2) medium supplemented with different concentrations of $\mathrm{MgCl}_{2}$, or (3) media with adjusted $\mathrm{pH}$ values. The control group was used without any supplement or $\mathrm{Mg}$ wire. After incubation at $37^{\circ} \mathrm{C}$ in $5 \% \mathrm{CO}_{2}$ for cell proliferation, $10 \mu \mathrm{L}$ Cell Counting Kit-8 (CCK-8) solution (DOJINDO, Japan) was added into each well, and the cells were incubated for another $4 \mathrm{~h}$. Thereafter, the absorbance of each well (optical density at $450 \mathrm{~nm}$ (OD450)) was tested using a microplate reader (ELX800, BioTek, USA). In the $\mathrm{H}_{2}$ exposure test, tumor cells were seeded on the upper chamber with a density of $2 \times 10^{5}$ cells per well and $\mathrm{Mg}$ wires were placed in the lower-chamber for two days. Cells in the up-chamber were treated with $100 \mu \mathrm{L}$ CCK-8 solution and transferred into 96-well plates for further proliferation test.

\section{Apoptosis analysis}

The MG63 and U2-OS cells were incubated in medium with different concentrations of $\mathrm{Mg}^{2+}(0,5,10$, $20 \mathrm{mmol} \mathrm{L}^{-1}$ ) or adjusted $\mathrm{pH}$ values $(7.4,7.7$ and 8.0$)$ for $48 \mathrm{~h}$ and were harvested for apoptosis analysis. The levels of apoptotic cells were measured by FITC Annexin V and propidium iodide solution (Sony Biotechnology, Japan), according to the manufacturer's instructions. The mixture solution was analyzed by a flow cytometer (CytoFLEX S, Beckman Coulter, USA).

\section{Intracellular ROS detection}

The level of intracellular reactive oxygen species (ROS) was detected by the ROS assay kit (Mlbio, Shanghai, China) according to the manufacturer's instructions.

Effect of $\mathrm{Mg}^{2+}$ on the half-life and nucleocytoplasmic ratio change of Snaill protein in OS cells

After 48 -h treatment with $\mathrm{Mg}^{2+}\left(20 \mathrm{mmol} \mathrm{L}^{-1}\right)$, MG63 cells were suspended in MEM with $10 \%$ fetal bovine serum (FBS), seeded to 6-well plates at a density of $2 \times 10^{5}$ cells per well. After overnight culture, the medium was replaced with serum-free MEM containing either $50 \mu \mathrm{mol} \mathrm{L}^{-1}$ MG132 or $100 \mu \mathrm{g} \mathrm{mL}^{-1}$ cycloheximide (CHX, sigma, USA). After being further cultured for $0.5,1,2,4$ and $8 \mathrm{~h}$, cells were collected and lyzed. The total protein was extracted and the expression of Snaill was detected by western blotting. At the same time, MG63 cells were treated with a gradient of $\mathrm{Mg}^{2+}\left(0,5,10\right.$ and $\left.20 \mathrm{mmol} \mathrm{L}^{-1}\right)$ for $48 \mathrm{~h}$, and the protein of Snail1 was located by immunofluorescence staining (1:200, Abcam, UK). The nucleus was separated and the nucleoprotein was extracted for nucleocytoplasmic ratio change assay of Snaill by western blotting.

\section{In vivo antitumor effect on tumor-bearing mouse model}

Our animal experiment was approved by the Experiment Animal Ethics Committee of the Second Military Medical University. MG63 cells $\left(1 \times 10^{6} \mu \mathrm{L}^{-1}\right)$ were suspended in $50 \mu \mathrm{L}$ medium, which was injected subcutaneously into the flank regions of 30 female athymic nude mice. Three weeks after inoculation, tumors were grown into a diameter of $2.5 \mathrm{~mm}$. These mice were randomly divided into five groups (six mice in each group), including a model group without any treatment, a stainless steel (SS) group, an $\mathrm{Mg}$-implanted group, an $\mathrm{Mg}$-implanted group combined with miRNA-181c/d-5p expression, as well as the Mg-implanted group with negative control (NC). For mice to be implanted with $\mathrm{Mg}, \mathrm{Mg}$ wires with an average diameter of $0.77 \mathrm{~mm}$ and an average length of $2.5 \mathrm{~mm}$ were inserted into tumors. The SS wires of the same size were inserted as a control. The miRNA-181c/d-5p $+\mathrm{Mg}$ represents overexpressed exogenous miRNA-181c/d-5p by lentivirus with inserted $\mathrm{Mg}$ wires. The $\mathrm{NC}+\mathrm{Mg}$ group represents an overexpressed control sequence of the miRNA-181c/d-5p and inserted Mg wires. Starting from the 2 nd week, each animal in all intervention groups was injected with $50 \mu \mathrm{L}$ lentivirus $\left(5 \times 10^{7} \mathrm{IFU}\right)$ twice a week, lasting for four weeks. The control model group were injected with the same volume of saline instead. For the Mg-implanted animals, the Mg wires were sterilized be- 
fore implantation. To plot the growth curve of the tumor, the diameter of the tumor was measured weekly since the 2 nd week. The volume of the tumor, $V$, was roughly estimated by $V=a b^{2} / 2$, in which $a$ and $b$ represent the length of the major and minor axis, respectively. Each group at different treatments was euthanatized on the 28th day after administration. Hematoxylin \& eosin (H\&E) and Ki67 assay were performed using tissues from subcutaneous tumorigenesis of MG63 cells. Images were collected with an inverted fluorescence microscope. The expressions of NLK and TIMP3, and phosphorylation of Snaill in subcutaneous tumors were quantified by western blotting, levels of miRNA-181c/d-5p were measured by real-time quantitative PCR (RT-qPCR).

\section{RT-qPCR}

The PCR system includes Takara SYBR Premix Ex Tap $(10 \mu \mathrm{L})$, forward and reverse primers $\left(20 \mu \mathrm{mol} \mathrm{L} \mathrm{L}^{-1}, 0.2 \mu \mathrm{L}\right.$ each), and $2 \mu \mathrm{L}$ of cDNA supplemented with deionized $\mathrm{H}_{2} \mathrm{O}$ to $20 \mu \mathrm{L}$. The cycling steps include 40 cycles, and each cycle contains denaturation at $95^{\circ} \mathrm{C}$ for $10 \mathrm{~s}$, annealing at $60^{\circ} \mathrm{C}$ for $20 \mathrm{~s}$, and elongation at $72^{\circ} \mathrm{C}$ for $20 \mathrm{~s}$. U6 snRNA was used as a reference to normalize the miRNA-181a/b/c/d-5p level using the $2^{\Delta \Delta \mathrm{Ct}}$ method. Each RNA sample was run in triplicate. The primers' sequences are shown in Table S1.

\section{Immunoblot analysis}

The total protein was extracted from the cells using the M-PER mammalian protein extraction reagent or from tissues using the T-PER tissue protein extraction reagent (Pierce, USA). An equal amount of protein $(20 \mu \mathrm{g}$ per lane) estimated by the bicinchoninic acid protein assay kit (Pierce) was loaded onto (11\%) SDS-PAGE gels and transferred onto nitrocellulose membranes. The blots were probed with a monoclonal antibody against human Snail1 (1:200), NLK (1:500), TIMP3 (1:600) and $\beta$-actin (1:1200, Abcam), followed by a secondary HRP-conjugated anti-rabbit antibody (Abcam) staining. After washing, the bands were detected by chemiluminescence and imaged with X-ray films. $\beta$-actin was used as an endogenous reference for normalization.

\section{Molecular docking analysis}

To analyze the inhibitory action of $\mathrm{Mg}$ by computational docking studies, a computational ligand-target docking approach was used to analyze structural complexes of the Snaill (target) with $\mathrm{Mg}^{2+}$ (ligand) to understand the structural basis of this protein target specificity. And the docking was carried out by the PyMOL and Autodock software.

\section{Statistical analyses}

All statistical analyses were performed using SPSS 20.0 (SPSS, Chicago, IL, USA). Data were expressed as mean \pm standard deviation (SD). Differences among groups were analyzed by one-way analysis of variance (ANOVA) followed by Least square difference's post hoc test. $p<0.05$ was considered a significant statistic difference.

\section{RESULTS}

\section{Microstructure characterization, mechanical properties and degradable properties of different $\mathrm{Mg}$ wires}

The microstructure and mechanical property of $\mathrm{Mg}$ wires were studied as shown in Fig. 1. During the whole drawing process, the diameter of $\mathrm{Mg}$ wire decreased gradually from 1.22 to $0.77 \mathrm{~mm}$. In this process, the deformation twin could be found in samples $\phi 1.22, \phi 1.0$ and $\phi 0.9$ (as marked arrow in Fig. 1a), except $\phi 0.77$, indicating the recrystallization in $\phi 0.77$ is more sufficient than that in other samples. Thus, grain refinement of $\phi 0.77$ was the most remarkable in all $\mathrm{Mg}$ wires. With the increase in drawing reduction, the grain size of $\mathrm{Mg}$ wires reduced. Fig. $1 \mathrm{~b}$ shows the stress-stain curves during the tensile test of these $\mathrm{Mg}$ wires. The ultimate tensile strength and elongation are shown in Fig. 1c. According to the Hall-Petch relation, decreasing the grain size can harden both metals and alloys [20]. Therefore, both of strength and elongation increase with the process of drawing (decrease in grain size). Finally, the sample $\phi 0.77$ which is used in vivo study of present work achieves good mechanical properties (UTS $(175 \pm 5.6) \mathrm{MPa}$, elongation $(4.8 \pm 0.5) \%)$.

The corrosion behavior of $\mathrm{Mg}$ wires was tested in an $\mathrm{m}$ SBF solution for 14 days. As time proceeded, we observed an increasing $\mathrm{pH}$ value of the medium, release of $\mathrm{H}_{2}$ bubbles and accumulation of $\mathrm{Mg}^{2+}$ in the $\mathrm{m}-\mathrm{SBF}$, in agreement with previous studies (Fig. S1a-c) [21]. The degradation rate declines with the proceeding of degradation until a stable degradation rate reached on the 4 th day. The corresponding release rate of hydrogen is about $250 \mu \mathrm{g} \mathrm{L}^{-1}$. With an extension of soaking time, the concentration of $\mathrm{Mg}^{2+}$ in the solution increases accordingly, and the slope of the $\mathrm{Mg}^{2+}$ release curve is observed to decline as a result of decreased corrosion rate. SEM observation reveals that a uniform Ca-P corrosion layer formed on the surface of $\mathrm{Mg}$ retards the corrosion, and $\mathrm{Mg}$ wire maintains integrity after 14-day immersion (Fig. S2). The corrosion rate of $\mathrm{Mg}$ was about $1 \mathrm{~mm}$ per year 
(Fig. S1d).

\section{Mg wires inhibit the viability of OS tumor cells}

To test whether the degradable $\mathrm{Mg}$ wires affect the viability of bone tumor cells, Mg wires were separately cultured with two kinds of common tumor cells, MG63 and $\mathrm{U} 2-\mathrm{OS}$. When four pieces of $\mathrm{Mg}$ wires were co-cultured with cells for $24 \mathrm{~h}$, the proliferation inhibition rate of MG63 and U2-OS cells were about $99 \%$ and 56\%, respectively (Fig. 2b, d). The more remarkable anti-tumor effect on MG63 cells is attributed to more degradation of $\mathrm{Mg}$ wires, and severe pitting corrosion is observed in the MG63 culture medium, but not in the U2-OS culture medium (Fig. 2a, c). The severe pitting corrosion in the MG63 culture medium is attributed to the presence of a higher concentration of $\mathrm{Cl}^{-}$in MEM than that in U2-OS (RPMI-1640) culture medium. Aggressive $\mathrm{Cl}^{-}$have been shown to react with the intermediate corrosion product of $\mathrm{Mg}$ and thus penetrate through the passivated corrosion layer, by which corrosion pits are formed.

\section{Effect of Mg corrosion products on the viability and apoptosis of cells}

To quantitatively understand how the degradation of $\mathrm{Mg}$
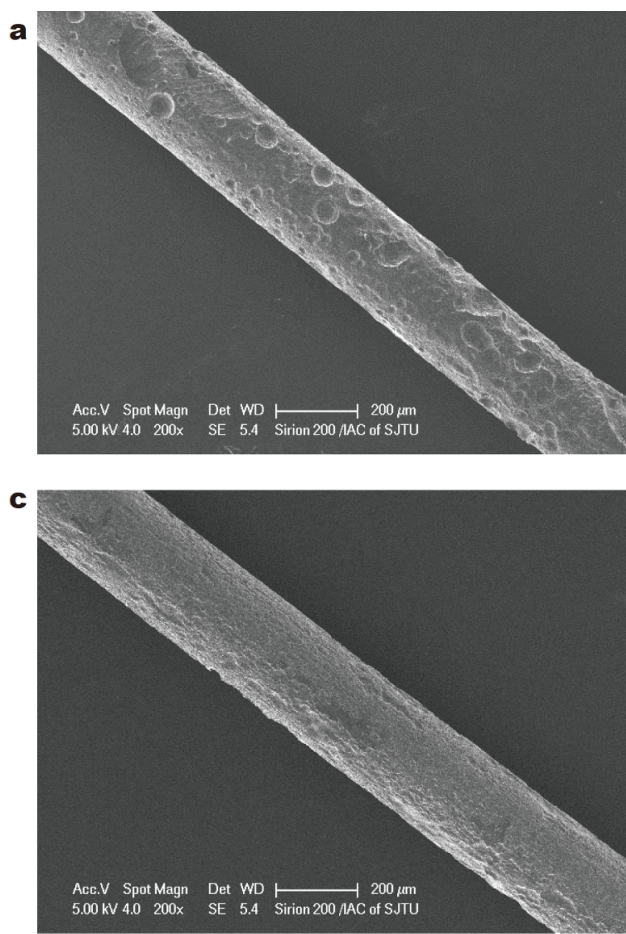

affects the viability of tumor cells, three independent degradation products of $\mathrm{Mg}$ on the cellular viability were separately studied.

\section{The effect of $\mathrm{pH}$ value}

Similar to the alkalization in $\mathrm{m}-\mathrm{SBF}$, degradation of $\mathrm{Mg}$ in the cell culture medium causes an increased $\mathrm{pH}$ from 7.4 to 8.0 during the first $24 \mathrm{~h}$, as shown in Fig. S3. To test the effect of $\mathrm{pH}$ while excluding the influence of $\mathrm{Mg}^{2+}$ or $\mathrm{H}_{2}$ exposure on the viability of cells, the initial $\mathrm{pH}$ values of the MEM or RPMI-1640 medium were adjusted to 7.4, 7.7 and 8.0. The increased alkalinity was not shown to impair the viability of the MG63 and U2-OS cells (Fig. S4) or change their apoptosis rate (Fig. S5).

\section{The effect of $\mathbf{H}_{2}$}

To control the level of hydrogen exposed to cells, a number of $\mathrm{Mg}$ wires (up to four pieces) were immersed into each well (Fig. 3a). To rule out the effects of the other two degradation products $\left(\mathrm{Mg}^{2+}\right.$ and $\left.\mathrm{pH}\right)$ on tumor cells, we tested the concentration of $\mathrm{Mg}^{2+}$ in the culture medium. We found there was no significant difference in the concentration of $\mathrm{Mg}^{2+}$ in the upper-medium of the three groups (Fig. 3b). It indicates that the upper chamber cell
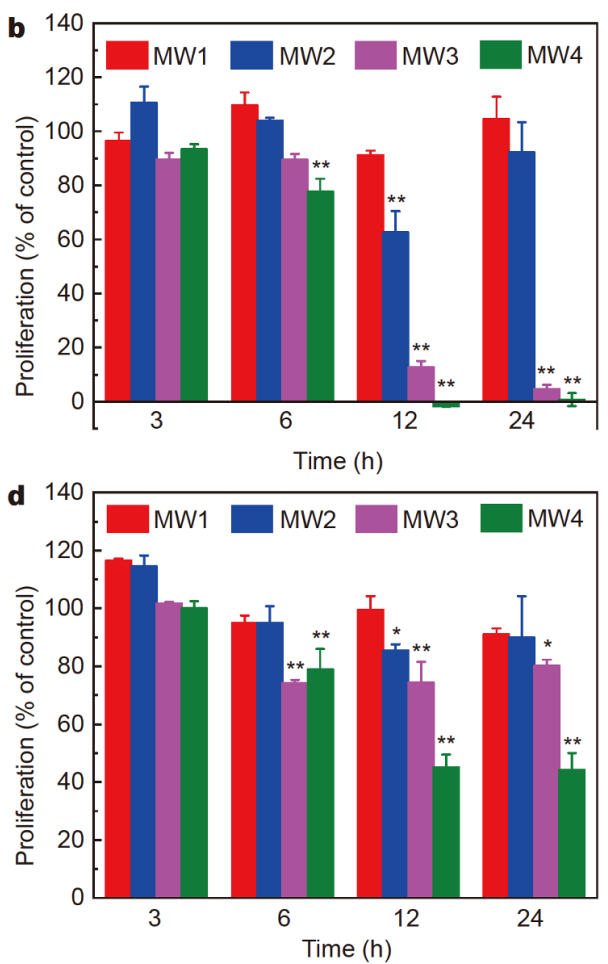

Figure $2 \mathrm{Mg}$ wires inhibit the viability of tumor cells. $(\mathrm{a}, \mathrm{c})$ SEM images showing the surface morphology of Mg wires immersed in the culture medium of MG63 cells (a) and U2-OS cells (c) for 24 h; (b, d) cell viability of MG63 (b) and U2-OS (d) cells after co-culture with different numbers of Mg wires (marked as MW 1, 2, 3 and 4 ). ${ }^{*} p<0.05 ;{ }^{* *} p<0.01$. 

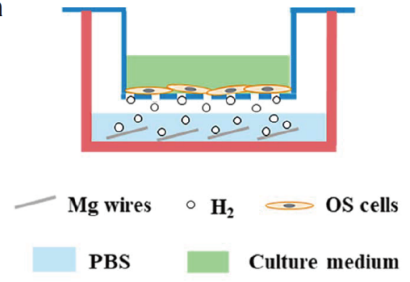

$\mathbf{C}$

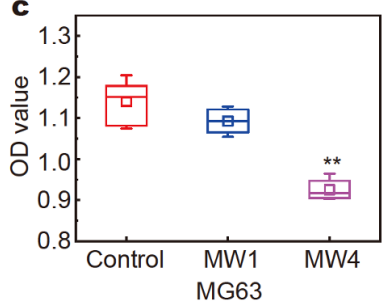

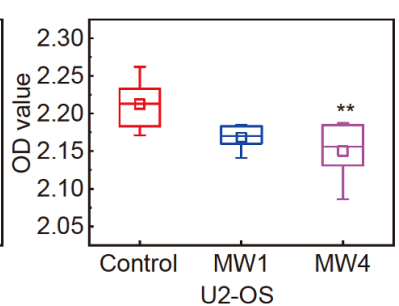
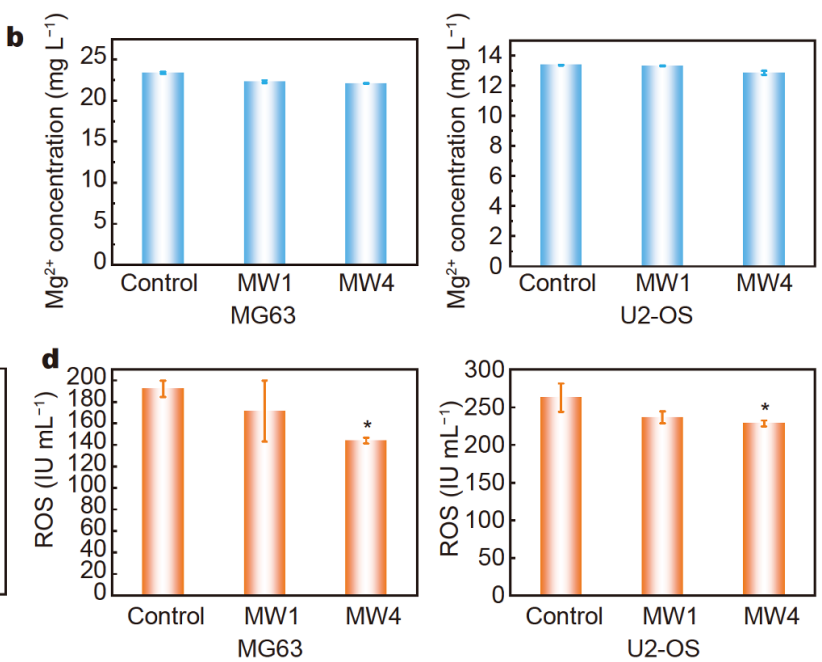

Figure 3 The effect of $\mathrm{H}_{2}$ on OS cells. (a) Schematic diagram of hydrogen release device; (b) concentration of Mg ions in the different culture medium of upper chamber; (c) cell viability of MG63 and U2-OS cells after exposure to $\mathrm{H}_{2}$; (d) levels of intracellular ROS of MG63 and U2-OS cells after exposure to $\mathrm{H}_{2}$. Data are expressed as mean $\pm \mathrm{SD} .{ }^{*} p<0.05 ;{ }^{*} p<0.01$.

culture and the lower chamber $\mathrm{Mg}$ degradation environment are not connected, only the $\mathrm{H}_{2}$ acts on the cells through upward diffusion. We next tested the effect of $\mathrm{H}_{2}$ on the viability of OS cells. As an important corrosion product of $\mathrm{Mg}$, hydrogen gas has been reported to affect the activity of tumor cells [22]. Hydrogen gas released from degraded $\mathrm{Mg}$ could pass through the cell membrane and partially eradicate the endogenous free radicals from tumor cells, evidenced by measuring the ROS released from lysed cells, as shown in Fig. 3c. With the sustained exposure to a higher dose of hydrogen, the proliferation of OS cells was inhibited (Fig. 3d) [23].

\section{The effect of $\mathrm{Mg}^{2+}$}

To test the influence of $\mathrm{Mg}^{2+}$ on the viability of tumor cells, $\mathrm{Mg}^{2+}$ was supplemented into the culture medium through the addition of $\mathrm{MgCl}_{2}$. As the addition of excessive $\mathrm{MgCl}_{2}$ may increase the osmolality of the cell culture medium and thereby causes cell death through osmotic dehydration [24]. To rule out the effect of high osmolality on OS cells, we tested the osmolality of MEM with different concentrations of $\mathrm{Mg}^{2+}$. As shown in Fig. $4 \mathrm{a}$, osmotic pressure has a linear relationship with $\mathrm{Mg}^{2+}$ concentration. The susceptibility of normal human bone cells C28/I2 to the excessive $\mathrm{Mg}^{2+}$ was tested. When the concentration of $\mathrm{Mg}^{2+}$ is no more than $20 \mathrm{mmol} \mathrm{L}^{-1}$, no significant statistical difference in the viability of normal bone cells was seen (Fig. 4b). In comparison, when MG63 and $\mathrm{U} 2-\mathrm{OS}$ cells were cultured in $\mathrm{Mg}^{2+}$-rich culture medium (10-20 $\left.\mathrm{mmol} \mathrm{L}^{-1}\right)$, the proliferation of tumor cells was significantly restrained (Fig. 4c, d). Particularly, the apoptosis rate of the OS cells was increased with the concentration of $\mathrm{Mg}^{2+}$. The apoptosis rate of MG63 cells treated with $20 \mathrm{mmol} \mathrm{L}^{-1} \mathrm{Mg}^{2+}$ was up to $53.89 \%$ compared with $10.27 \%$ without $\mathrm{Mg}^{2+}$ treatment, and the apoptotic rate of U2-OS increased from $6.45 \%$ to $67.55 \%$ with the $20 \mathrm{mmol} \mathrm{L}^{-1} \mathrm{Mg}^{2+}$ treatment (Fig. $4 \mathrm{e}, \mathrm{f}$ ).

Combining the degradable properties of $\mathrm{Mg}$ wires, we found that $\mathrm{Mg}^{2+}$ and $\mathrm{H}_{2}$ could inhibit the growth of OS cells. The excessive $\mathrm{Mg}^{2+}$ exhibited pronounced antitumor activity, hence we next investigated the mechanism of $\mathrm{Mg}$ wires on tumor cells by regulating the $\mathrm{Mg}^{2+}$.

\section{$\mathrm{Mg}^{2+}$-mediated signaling pathway for inhibition of $\mathrm{OS}$}

To further clarify the molecular mechanism supporting the anti-OS effect of $\mathrm{Mg}$ wires, we explored the $\mathrm{Mg}^{2+}$-involving signaling pathway for suppression of tumor cells. Snaill is a transcription factor that plays vital roles in various physiological processes of OS, and the statistics of the clinical case have shown that Snaill is highly expressed in tumor cells (Fig. S6) [25-27]. However, it remains unknown whether $\mathrm{Mg}^{2+}$ modulates the activation of Snaill. Hence, computational docking analysis was performed to analyze the interaction between $\mathrm{Mg}^{2+}$ and the target protein Snaill. According to the results, we found $\mathrm{Mg}^{2+}$ had contacts with Cys and His residues of the protein (Fig. 5a). Therefore, Snaill is proposed as a target protein in the downstream of the 

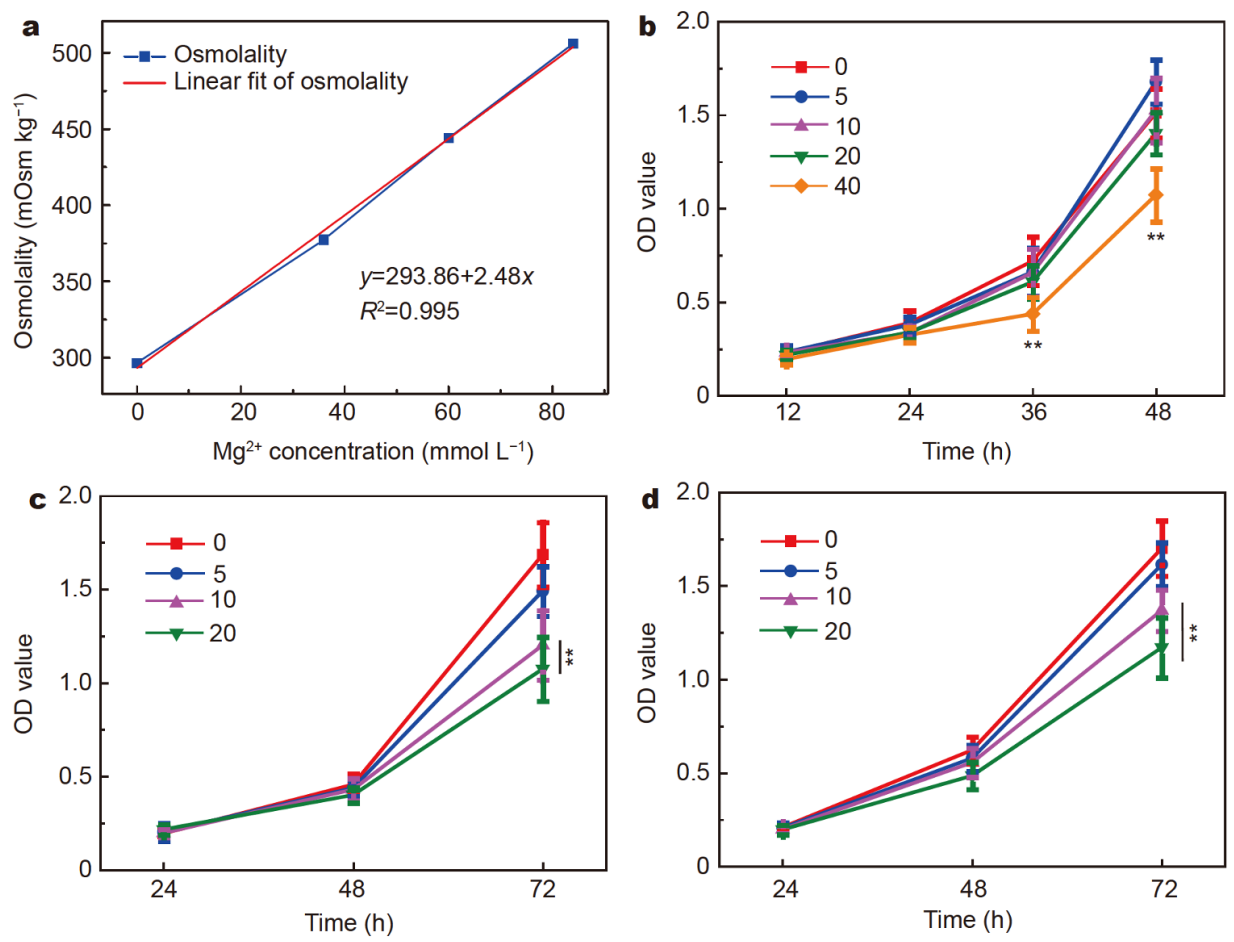

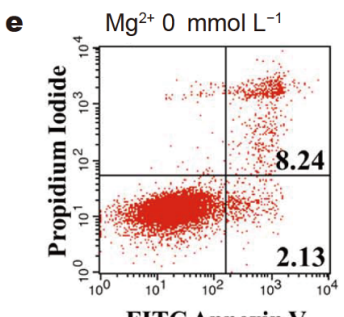

FITC Annexin V

f

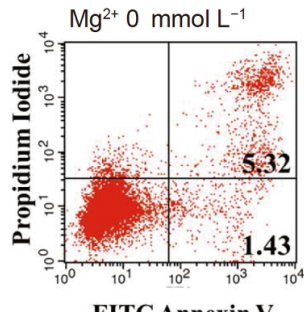

FITC Annexin V

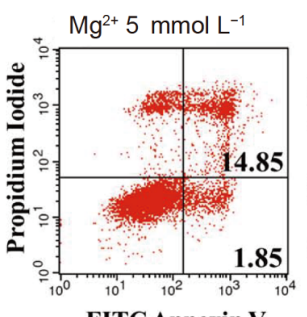

FITC Annexin V

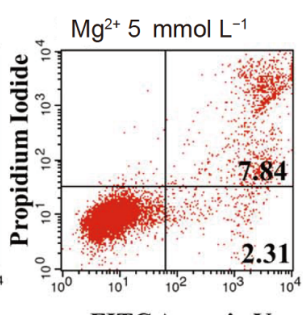

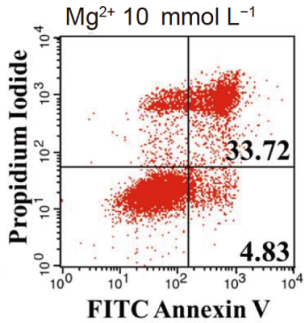
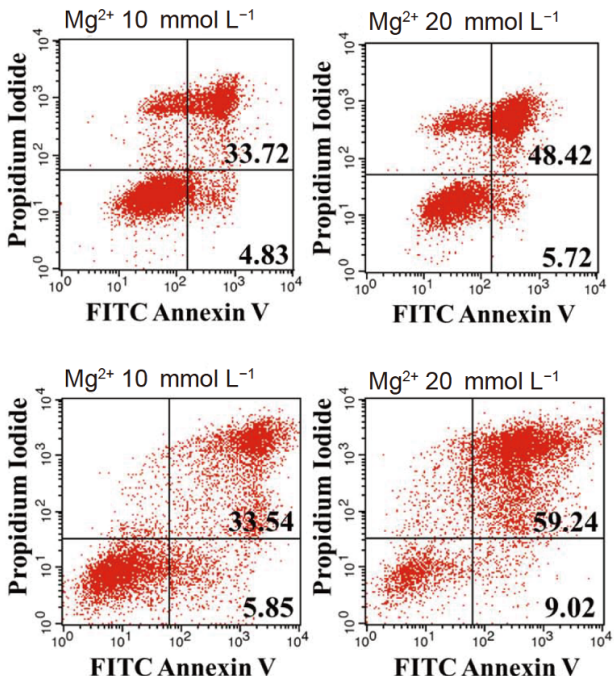

Figure 4 The effect of $\mathrm{Mg}^{2+}$ on normal human bone cells (C28/I2) and OS cells (MG63 and U2-OS). (a) The osmolality of MEM supplemented with different concentrations of $\mathrm{Mg}^{2+}$; (b) cell proliferation of normal human bone cells (C28/I2) in medium of different concentrations of $\mathrm{Mg}^{2+}$ for 12,24 , 48 and $72 \mathrm{~h}$, respectively; (c, d) cell viability of MG63 and U2-OS in medium with $\mathrm{Mg}^{2+}$ concentrations of $0,5,10$ and 20 mmol $\mathrm{L}^{-1}$; (e, f) apoptosis rates of MG63 and U2-OS with different concentrations of $\mathrm{Mg}^{2+}$ in medium. Data are expressed as mean $\pm \mathrm{SD} .{ }^{*} p<0.05$; ${ }^{* *} p<0.01$.

$\mathrm{Mg}^{2+}$-activated pathway for inhibition of OS cells.

\section{$\mathrm{Mg}^{2+}$ promotes nuclear import and phosphorylation of Snaill protein}

Snaill has been reported to modulate the epithelial-tomesenchymal transition by suppressing E-cadherin dur- ing the metastasis of cancer [28]. The cytological function of Snail1 is regulated by the level of phosphorylation and its subcellular localization. Different from healthy bone cells, Snail1 protein mainly distributes in the cytosol of OS cells, as shown in Fig. 5b. After MG63 cells were cultured in $\mathrm{Mg}^{2+}$-enriched medium for $48 \mathrm{~h}$, the majority 

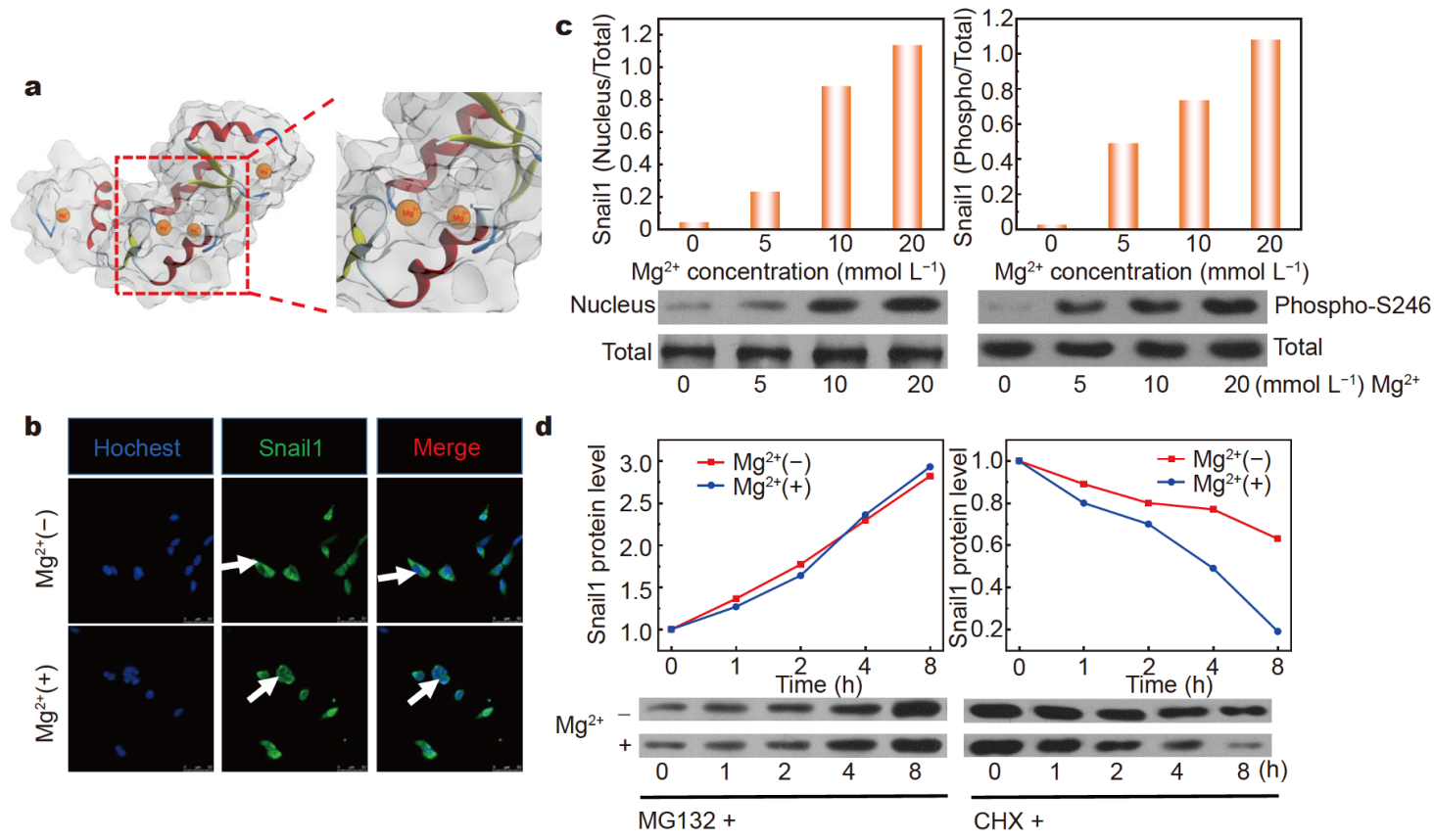

Figure 5 Effect of $\mathrm{Mg}^{2+}$ on the expression and distribution of Snail1 protein. (a) The contacts of $\mathrm{Mg}^{2+}$ and Snaill protein by protein docking; (b) immunofluorescence staining of Snail1 in MG63 cells for $48 \mathrm{~h}$. Scale bar: $50 \mu \mathrm{m}$. (c) Distribution of Snaill in cell nucleus relative to the total protein (left) and phosphorylation of Snaill (right) after treatment with $0,5,10,20 \mathrm{mmol} \mathrm{L}^{-1} \mathrm{Mg}^{2+}$; (d) cellular synthesis (left) and half-life time (right) of Snaill after treatment with $\mathrm{Mg}^{2+}$ in the indicated concentrations.

of the Snail1 protein was observed to translocate into the nucleus, as shown by the immunofluorescence staining in Fig. 5b. Western blotting data further confirmed that the phosphorylated Snail1 in MG63 cells were imported back to the nucleus with the increasing $\mathrm{Mg}^{2+}$ concentration in the culture medium. Correspondingly, the transcriptional activity of Snail1 in the nucleus was increased (Fig. 5c). By separately inhibiting the pathways of intracellular protein synthesis and degradation using $50 \mu \mathrm{mol} \mathrm{L}^{-1}$ of CHX and $10 \mu \mathrm{mol} \mathrm{L}^{-1}$ of MG132, we found that the halflife of Snaill became shortened after treatment with excessive $\mathrm{Mg}^{2+}$, which may be attributed from the accelerated ubiquitination and degradation of Snaill inside the nucleus (Fig. 5d).

Effect of $\mathrm{Mg}^{2+}$ on the expressions of miRNA-181 $/ \mathrm{d}-5 \mathrm{p}$ and their target proteins

NLK and TIMP3 proteins are key regulators for proliferation, migration, and invasion of tumor cells $[29,30]$. In the previous work, miRNA-181-5p has been shown to directly target the antitumor proteins of NLK and TIMP3 [31]. To elucidate whether $\mathrm{Mg}^{2+}$ regulates the expressions of NLK and TIMP3 through the miRNA-regulated posttranscription, changes in the miRNAs were determined through RT-qPCR and the expression levels of the target proteins were tested by western blotting. We found that the NLK and TIMP3 proteins were overexpressed after $\mathrm{Mg}^{2+}$ treatment, as shown in Fig. S7. The expressions of miRNA-181c-5p and miRNA-181d-5p in OS cells were down-regulated with increasing $\mathrm{Mg}^{2+}$ (Fig. S8). Therefore, $\mathrm{Mg}^{2+}$ promotes the death of OS cells by increasing the NLK and TIMP3 expressions through the miRNA-regulated post-transcription.

Analysis of two parallel pathways of $\mathrm{Mg}^{2+}$ on anti-OS effect In order to investigate the inhibitory pathway of OS cells activated by $\mathrm{Mg}^{2+}$, a lentiviral approach was used for the expressions of Snail1 and miRNA-181c/d-5p, and the silence of NLK and TIMP3 proteins. The gene delivery efficiency (evaluated by calculating the percentage of the cells expressing GFP relative to the total cells) was over $90 \%$, indicating a success of lentivirus transfection, as shown in Fig. S9. Our results show that the expression of Snail 1 was not affected by the overexpressed miRNA$181 \mathrm{c} / \mathrm{d}-5 \mathrm{p}$ or by deleting the NLK/TIMP3 proteins. The overexpression of Snail1 in the cell nucleus significantly reduced the level of miRNA-181c/d-5p, and the expressions of NLK and TIMP3 proteins were promoted. In addition, an elevated level of miRNA-181c-5p can deactivate the NLK protein system, and the increasing level of 
miRNA-181d-5p deactivated the expression of TIMP3 protein (Figs S10 and S11). These observations indicate that Snaill activates the expressions of NLK and TIMP3 by down-regulating the expressions of miRNA-181c-5p and miRNA-181d-5p.

The effect of the pathway on the proliferation, apoptosis, invasion and migration of $O S$ cells

As shown in Fig. S12, an up-regulated level of miRNA181c-5p or miRNA-181d-5p promotes the proliferation of MG63 cells, while excessive $\mathrm{Mg}^{2+}\left(20 \mathrm{mmol} \mathrm{L}^{-1}\right)$ can inhibit the growth of OS cells by down-regulating the expression of miRNA-181c/d-5p. We also carried out an invasion and wound healing assays to separately track the invasion and migration of MG63 cells transfected by lentivirus. Results show that excessive $\mathrm{Mg}^{2+}$ successfully reduced the invasion and migration of MG63 cells, compared with the control medium supplemented with a normal concentration of $\mathrm{Mg}^{2+}$ (Figs S13 and S14). Ad- ditionally, the TUNEL assay showed the apoptosis of MG63 cells was enhanced in the presence of excessive $\mathrm{Mg}^{2+}$. In contrast, the $\mathrm{Mg}^{2+}$-induced apoptosis was greatly diminished after the cells were transfected with miRNA181c-5p and miRNA-181d-5p (Fig. S15). These observations confirm that $\mathrm{Mg}^{2+}$ can effectively suppress the expression of miRNA-181c/d-5p, by which the proliferation, invasion, migration of OS cells were strongly inhibited.

\section{The anti-tumor effect of $\mathrm{Mg}$ wires in vivo}

In our attempt to further use $\mathrm{Mg}$ scaffold as a new antiOS therapy, animal experiments were carried out by transplanting MG63 tumor xenograft on nude mice. Changes in the volume of the tumors were recorded for four weeks (Fig. 6a). Compared with the mice in the model group without implantation of $\mathrm{Mg}$ wires, the implantation of $\mathrm{Mg}$ wires could significantly inhibit the growth of subcutaneous tumors, while the rapid growth
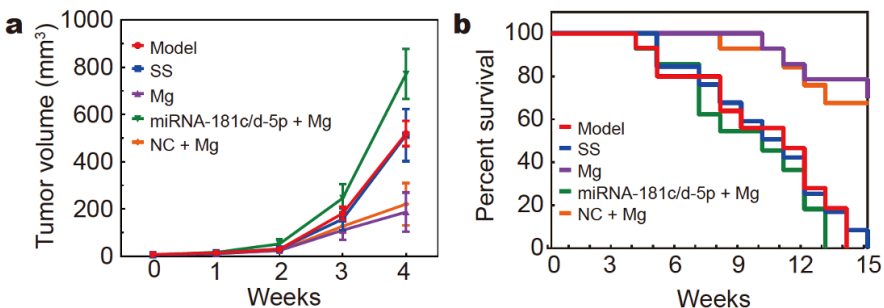

\section{e}
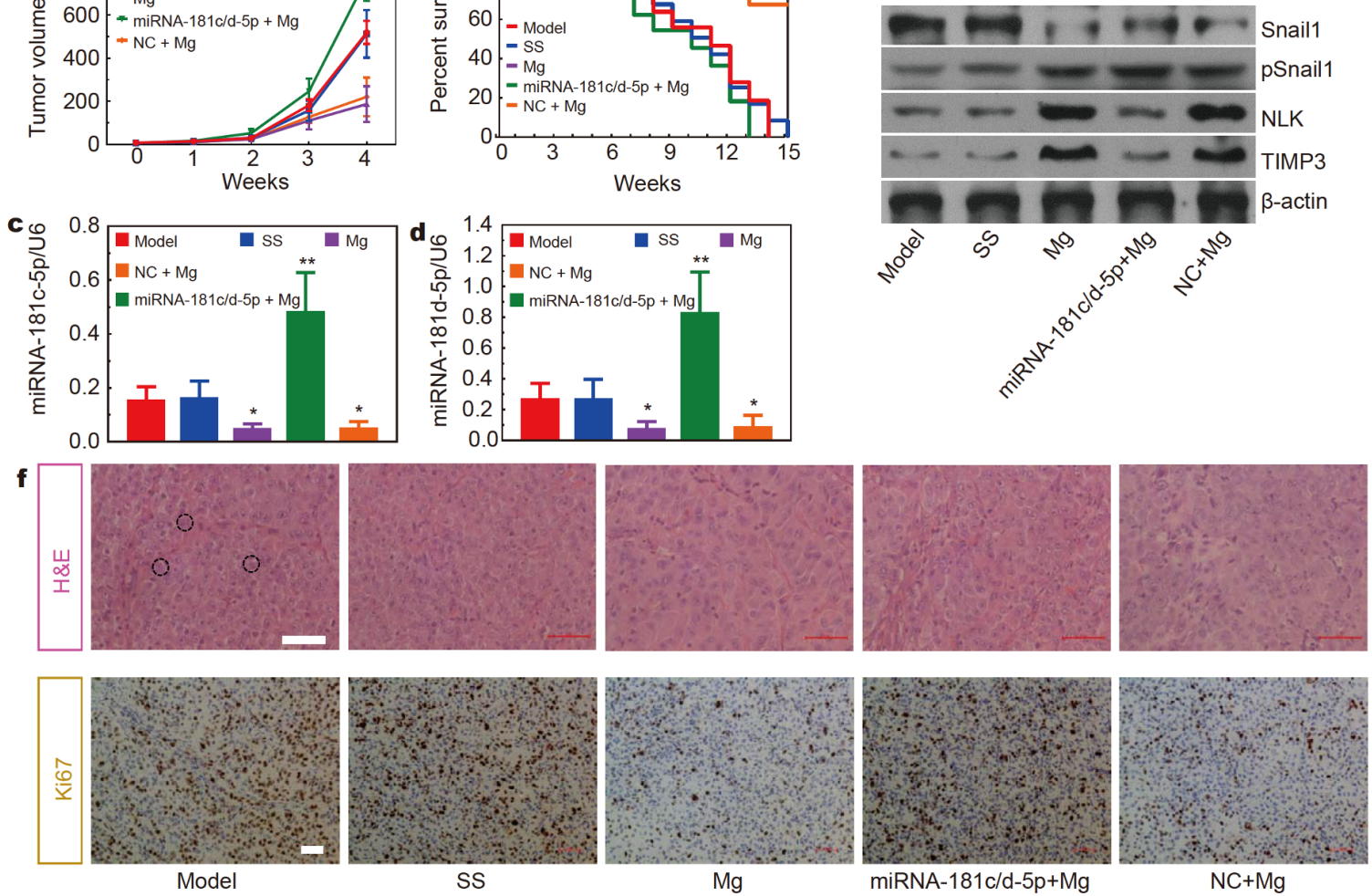

Figure 6 Anti-tumor effect of $\mathrm{Mg}$ in vivo. (a) The volume of tumors in MG63 tumor-bearing mice after different treatments $(n=6)$; (b) survival rate of mice with different treatments for 15 weeks $(n=12)$; $(c, d)$ quantitative measurement of miRNA-181c-5p and miRNA-181d-5p in tumors with different treatments; (e) the expressions of Snail1, pSnaill, NLK and TIMP3 in tumors after different treatments. $\beta$-actin treatment was used as a reference. (f) H\&E and Ki67 staining of tumor sections from each group, scale bar: $50 \mu \mathrm{m}$. Images were collected on the 28th day. Data are expressed as mean $\pm \mathrm{SD}$. ${ }^{*} p<0.05 ;{ }^{* *} p<0.01$. 
of tumors was observed in the miRNA-181c/d-5p overexpressed group. It should be noted that the suppressed growth of tumors in mice was not elicited by the operative injury. When SS wires were implanted into the same position of the nude mice, the growth of the tumor was not suppressed. The survival rate of the Mg-implanted animal group was $100 \%$ at the 10 th week, which declined to $66.67 \%$ at the 15 th week, as shown in Fig. 6b. In comparison, a drastic death rate was noticed since the 4 th week for the Mg-free animal group and all mice died in the 14th week. The death rate of miRNA-181c/d-5p + Mg group drops even faster than that of the model group. In addition, the biosafety of $\mathrm{Mg}$ implantation was evaluated by H\&E staining of major organs. As depicted in Fig. S16, no obvious pathological changes were found in the heart, liver, spleen, lung, and kidney after different treatments, reflecting no side effect of $\mathrm{Mg}$ wires in vivo. An analysis of the homogenized tumor tissues revealed that $\mathrm{Mg}$ wire can promote the activity and degradation of Snaill protein. Subsequently, it down-regulates the expressions of miRNA-181c-5p and miRNA-181d-5p, by which the expressions of NLK and TIMP3 were elevated (Fig. 6c-e). This observation is consistent with the in vitro observation that $\mathrm{Mg}^{2+}$ induces the death of tumor cells by the parallel pathway. In the H\&E staining study, a lower density of tumor cell nuclei was observed (violet) and the shape of cells is relatively homogeneous in the Mg group. In contrast, the tumor cells in the model group have hyperchromatic nuclei, scant cytoplasm, and polygonal cellular shape, as depicted in Fig. 6f. Furthermore, more tumor cells are arrested in the division stage (labeled in black circle) in the model group compared with the $\mathrm{Mg}$ group. In addition, the proliferating cell nuclear antigen (Ki67) measurement also indicates that Ki67-positive (brown) tumor cells decline quickly after treatment with $\mathrm{Mg}$ wires, i.e., the tumor cell proliferation was significantly inhibited. However, the overexpression of miRNA-181c/d-5p by lentivirus promoted the division and growth of the OS tumor cells (Fig. 6f), yielding increased mortality in nude mice.

\section{DISCUSSION}

Previous studies have reported that Mg-based biodegradable materials can significantly promote the regeneration of bone in bone defect and thereby they have been widely employed as bone screws and scaffolds for orthopedic implantation [32]. Despite their general biosafety and biocompatibility, the clinical effectiveness of this anti-tumor material to patients with fatal diseases, such as bone cancers, needs further investigation
[10,33,34]. Qiao et al. [35] reported that Mg inhibited the growth of ovarian cancer cells in vitro and in vivo. Yang et al. [36] found that $\mathrm{Mg}$ alloy killed murine breast cancer cells and rabbit hepatocellular carcinoma cells using magnetic hyperthermia therapy. Herein, we explored whether the Mg implantation could inhibit the relapse of bone tumor cells while exploited as a scaffold after the surgery. First, we prepared $\mathrm{Mg}$ wires of different diameters and found that the $\phi 0.77 \mathrm{Mg}$ wire showed an excellent mechanical property and a stable corrosion rate of approximately $1 \mathrm{~mm}$ per year. (Fig. 1 and Fig. S1). SEM images also showed unbroken $\mathrm{Mg}$ wires after long time immersion. These results indicate the robustness of using Mg implants for providing long-term mechanical support to bone rehabilitation and cancer therapy.

Subsequently, the Mg wires were co-cultured with the OS cells for $24 \mathrm{~h}$, and dramatically damaged the growth of the cells. Impressively, the inhibiting rate of MG63 cells reaches up to $99 \%$. Based on the prominent anti-tumor effect, we separately studied the effects of three $\mathrm{Mg}$ degradation products $\left(\mathrm{pH}, \mathrm{H}_{2}\right.$ and $\mathrm{Mg}^{2+}$ ) on MG63 and U2OS cells to further investigate the mechanism of $\mathrm{Mg}$ wires against the bone tumor. In recent studies, $\mathrm{Mg}$ and $\mathrm{Mg}$ alloys exhibited anti-tumor properties after immersed in extracts of cell culture medium [18]. The antitumor effect of $\mathrm{Mg}$ has been mainly ascribed to the rapid alkalization of the culture solution. The statement is well-established when the volume of the culture solution is relatively small compared with the exposed surface area of $\mathrm{Mg}$ in vitro. However, the rapid alkalinization is less reproducible in vivo due to the $\mathrm{pH}$ buffer system in the body. Accordingly, our study suggests that a mild $\mathrm{pH}$ increase from 7.4 to 8.0 did not affect the proliferation and apoptosis of OS cells (Figs S4 and S5). Increased generation of ROS has long been observed in tumor cells, and Ohsawa et al. [37] found that $\mathrm{H}_{2}$ can selectively eliminate the hydroxyl radical which is the most cytotoxic of ROS in tumor cells, while not affecting the role of ROS in normal cells. Here, we designed a unique device that releases hydrogen from $\mathrm{Mg}$ and found $\mathrm{H}_{2}$ can interfere with the growth of the OS cells by eradicating the overproduced ROS in MG63 and U2-OS cells, but not efficiently kill them (Fig. 3) $[18,19,38]$.

The discrepancy between the limited tumor death induced by alkalinity $/ \mathrm{H}_{2}$ in vitro and the pronounced antitumor activity of $\mathrm{Mg}$ in mice suggest a potential antitumor activity of excessive $\mathrm{Mg}^{2+}$. Excessive $\mathrm{Mg}$ ions were generated through the decomposition of $\mathrm{Mg}(\mathrm{OH})_{2}$ and their accumulative concentration increased with the degradation of $\mathrm{Mg}$ over time. Within the tested range of 
$\mathrm{Mg}^{2+}$ concentrations from 5 to $20 \mathrm{mmol} \mathrm{L}^{-1}$, faster growth of human osteoblast cells has been reported, and the rehabilitation of bone fracture is also accelerated in vivo $[11,39]$. Similarly, we found that $5-20 \mathrm{mmol} \mathrm{L}^{-1}$ of $\mathrm{Mg}^{2+}$ was not toxic to normal bone cells. When the concentration of $\mathrm{Mg}^{2+}$ was elevated to $10-20 \mathrm{mmol} \mathrm{L}^{-1}$, we demonstrated that the proliferation of MG63 and U2OS cells were suppressed and their apoptosis rates were increased. The osmolality of culture medium supplemented with $20 \mathrm{mmol} \mathrm{L}^{-1} \mathrm{MgCl}_{2}$ is about $344 \mathrm{mOsm} \mathrm{kg}^{-1}$ (Fig. 4a), which is not harmful to normal cells. However, an even higher dose of $\mathrm{Mg}^{2+}\left(\sim 40 \mathrm{mmol} \mathrm{L}^{-1}\right)$ will affect the viability of bone cells, attributed to the high osmolality of culture medium. An optimized medium supplemented with about $20 \mathrm{mmol} \mathrm{L}^{-1} \mathrm{MgCl}_{2}$ inhibited the proliferation of MG63 and U2-OS cells by promoting their apoptosis.

The anti-tumor effect of excessive $\mathrm{Mg}^{2+}$ could be explained within the framework of competitive transportation of $\mathrm{Mg}^{2+}$ and $\mathrm{Ca}^{2+}$ through the TRPM7 channel [40], a ubiquitous ion channel controlling the transportation of divalent cations and activation of Snaill protein [41]. In patients with colon neoplasia, the homeostasis of $\mathrm{Mg}^{2+}$ is frequently impaired and the cellular absorption ratio of $\mathrm{Ca}^{2+} / \mathrm{Mg}^{2+}$ is elevated. The deficient cellular uptake of $\mathrm{Mg}$ will activate the Snail 1 pathways and promote the epithelia-to-mesenchymal transition (EMT). In a typical process, more Snaill protein was observed to transport from the nucleus to cytoplasm, which clinically correlates to the formation of malignant carcinoma and increased mortality in patients with cancers (Fig. S6) [42]. Interestingly, the increasing $\mathrm{Mg}$ intake has been shown to negatively correlate to the risk of colorectal adenoma, indicating that excessive $\mathrm{Mg}$ may revert the viability of these cancer cells.

$\mathrm{As}_{\mathrm{Mg}^{2+}}$ competes with $\mathrm{Ca}^{2+}$ for the same transporters, in our study, the presence of excessive $\mathrm{Mg}^{2+}$ (a natural antagonist of calcium ion) may suppress the cellular absorption ratio of $\mathrm{Ca}^{2+} / \mathrm{Mg}^{2+}$, thus further restricting the transportation of Snaill proteins from nucleus to cytoplasm. According to the protein docking analysis, $\mathrm{Mg}^{2+}$ may bind to multiple sites to activate Snaill channel (Fig. 5a). Once activated, Snaill may transport from the cytoplasm back to the nucleus, where ubiquitylation and degradation of the Snaill occur (Fig. 5c, d) [42,43]. As a hematopoietic lineage modulator, the miRNA-181 family is involved in the Snaill-mediated EMT process [44]. When Snail1 ubiquitinates in the nucleus, it down-regulates the expressions of miRNA-181c-5p and miRNA$181 \mathrm{~d}-5 \mathrm{p}$ in OS cells (Fig. S8). The change of miRNA-181$5 \mathrm{p}$ then modulates downstream target protein, such as NLK and TIMP3. It has been reported that NLK protein is a key suppressor against the proliferation and migration of tumor cells $[29,43]$, and TIMP3 protein performs as a key regulator to apoptotic tumor cells [30,45]. Herein, we report a new mechanism about $\mathrm{Mg}$ wire-induced death of OS cells, as depicted in Scheme 1. In brief, we found that $\mathrm{Mg}$ wires sustainedly degraded to produce

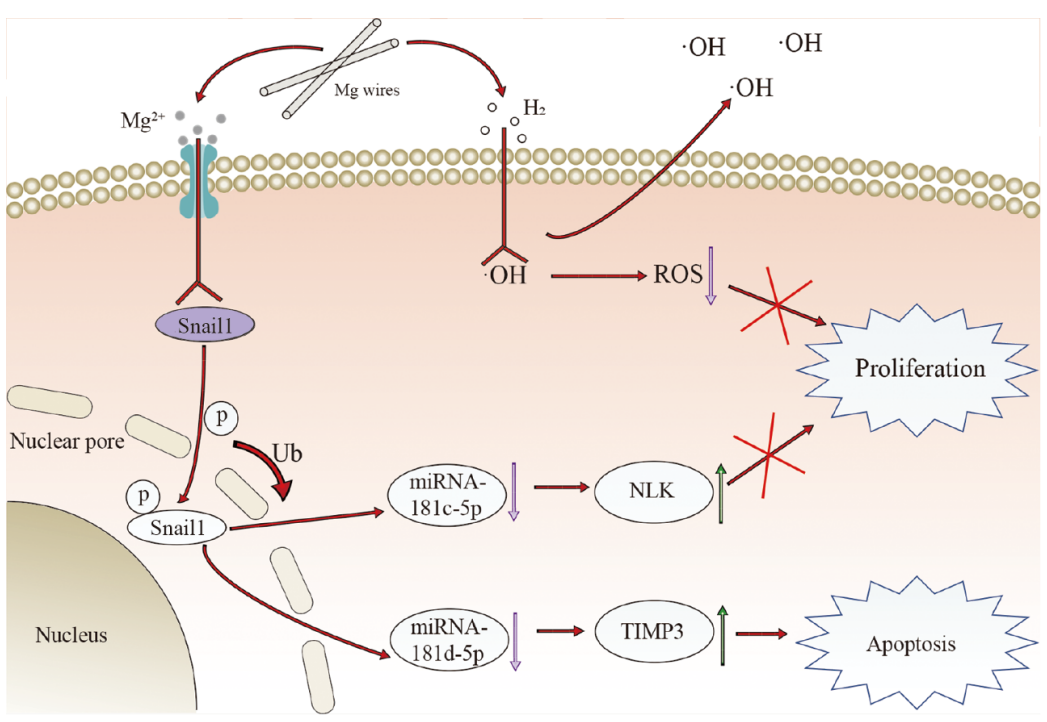

Scheme 1 A schematic diagram showing how the biodegradable magnesium stimulates the molecular pathway for inhibition of $\mathrm{OS}$ cells. $\mathrm{Mg}^{2+}$ released from the $\mathrm{Mg}$ wires promotes the phosphorylation and nuclear import of protein Snaill. The increase in the transcriptional activity of Snaill down-regulates miRNA-181c-5p and miRNA-181d-5p, which enhances the expressions of proteins of NLK and TIMP3. At the same time, $\mathrm{H}_{2}$ released by $\mathrm{Mg}$ quenches excessive $\cdot \mathrm{OH}$ inside cells, reduces the ROS level and modulates cell proliferation. 
$\mathrm{Mg}^{2+}$ which could induce apoptosis of OS cells without causing damage to normal cells. To understand this antitumor phenomenon, we tried and established the regulation theory and mechanism of $\mathrm{Mg}^{2+}$ on inhibiting the progression of OS tumors with the nuclear transcription factor Snaill, a key protein in regulating EMT and tumor progression as the core [46]. We found that a suitable concentration of $\mathrm{Mg}^{2+}$ can shorten the half-life of Snaill in tumor cells by changing the nuclear to cytoplasmic ratio, resulting in a decrease of Snaill expression. Our mechanism study showed that $\mathrm{Mg}^{2+}$ could inhibit the proliferation and induce apoptosis of OS tumor cells through the two parallel pathways: Snail1/miRNA-181c$5 \mathrm{p} / \mathrm{NLK}$ and Snail1/miRNA-181d-5p/TIMP3, which is consistent with the previous meta-analysis of the antitumor effect of $\mathrm{Mg}^{2+}$ [47]. In the meantime, $\mathrm{Mg}$ wires perform a unique anti-tumor effect by exposing molecular $\mathrm{H}_{2}$ to disturb the physiological redox homeostasis in bone tumor cells.

In view of other metallic orthopedic implants in clinical trials, titanium ( $\mathrm{Ti}$ ) alloys and SS are frequently used in OS operation. However, residual OS cells often cause OS recurring from long-term clinical observations [6]. Compared with traditional implanted materials, biodegradable $\mathrm{Mg}$ exhibited a unique anti-tumor effect ascribed to its degraded products. Compared with the model group, $\mathrm{Mg}$ wires inserted into the tumor effectively restricted the size of tumors and prolonged the lifetime of mice. In addition, the implanted $\mathrm{Mg}$ wires avoided damage to normal tissue, which is safe for clinical use. RTqPCR and western blotting revealed Mg wires activated Snaill to degrade and the expressions of TIMP3 and NLK protein were up-regulated. In the meantime, $\mathrm{Mg}$ wires down-regulated the expression of miRNA-181c/d-5p. The parallel pathway of $\mathrm{Mg}$ wires inhibits OS cell growth, in agreement with the observations of in vitro test.

So far, a list of metal/metal oxide has been proved to be useful in promoting apoptosis of cancer cells, e.g., zinc acts as a tumor suppressor on the malignant cells by interacting with our immune system $[48,49]$; iron oxide, a degradation product of Fe implants, induces antitumor activity in tumor-associated macrophages [50]. Compared with other anti-tumor metals, the magnesium (and its degradation products) is a well-tolerant macroelement in our body, and the use of Mg-based implants is expected to develop a safe anti-tumor strategy.

\section{CONCLUSIONS}

In summary, the specialized $\mathrm{Mg}$ wires are considered as the desired scaffold after bone tumor surgery. The mo- lecular biology underlying the anti-tumor effect of $\mathrm{Mg}$ wires was reported for the first time. Mg wire produces $\mathrm{H}_{2}$ that alerts redox status in bone tumor cells and inhibits their proliferation. In addition, we showed that excessive $\mathrm{Mg}^{2+}$ from $\mathrm{Mg}$ wires can inhibit the proliferation and induce apoptosis of OS cells through Snaill/ miRNA-181c-5p/NLK and Snail1/miRNA-181d-5p/ TIMP3 pathway. In consistent with in vitro observations, our animal tests also highlight the importance of $\mathrm{Mg}$ wire-associated inhibition pathway in vivo. Compared with the SS, the implanted $\mathrm{Mg}$ wires effectively restrict the size of tumors and prolong the lifetime of mice with OS. Therefore, the safety and efficient $\mathrm{Mg}$ wires have a great promise in the future application for bone tumors in clinical surgery.

\section{Received 12 May 2020; accepted 28 August 2020;}

published online 24 November 2020

1 Ottaviani G, Jaffe N. The Epidemiology of Osteosarcoma. In: Jaffe $\mathrm{N}$, Bruland $\mathrm{O}$, Bielack S, eds. Pediatric and Adolescent Osteosarcoma. Boston: Springer, 2010

2 Siegel RL, Miller KD, Jemal A. Cancer statistics, 2018. CA Cancer J Clin, 2018, 68: 7-30

3 Eilber F, Giuliano A, Eckardt J, et al. Adjuvant chemotherapy for osteosarcoma: A randomized prospective trial. J Clin Oncol, 1987, 5: $21-26$

4 Ritter J, Bielack SS. Osteosarcoma. Ann Oncol, 2010, 21: vii320

5 Ma $\mathrm{H}$, Jiang $\mathrm{C}$, Zhai $\mathrm{D}$, et al. A bifunctional biomaterial with photothermal effect for umor therapy and bone regeneration. Adv Funct Mater, 2016, 26: 1197-1208

6 Han $\mathrm{P}$, Cheng $\mathrm{P}$, Zhang $\mathrm{S}$, et al. In vitro and in vivo studies on the degradation of high-purity $\mathrm{Mg}$ (99.99 wt.\%) screw with femoral intracondylar fractured rabbit model. Biomaterials, 2015, 64: 57-69

7 Lai Y, Li L, Chen S, et al. A novel magnesium composed PLGA/ TCP porous scaffold fabricated by $3 \mathrm{D}$ printing for bone regeneration. J Orthopaedic Trans, 2014, 2: 218-219

8 Brar HS, Platt MO, Sarntinoranont M, et al. Magnesium as a biodegradable and bioabsorbable material for medical implants. J Miner Met Mater Soc, 2009, 61: 31-34

9 Witte F. The history of biodegradable magnesium implants: A review. Acta Biomater, 2010, 6: 1680-1692

10 Zhao D, Witte F, Lu F, et al. Current status on clinical applications of magnesium-based orthopaedic implants: A review from clinical translational perspective. Biomaterials, 2017, 112: 287-302

11 Zhang Y, Xu J, Ruan YC, et al. Implant-derived magnesium induces local neuronal production of CGRP to improve bone-fracture healing in rats. Nat Med, 2016, 22: 1160-1169

12 Zhang L, Pei J, Wang H, et al. Facile preparation of poly(lactic acid)/brushite bilayer coating on biodegradable magnesium alloys with multiple functionalities for orthopedic application. ACS Appl Mater Interfaces, 2017, 9: 9437-9448

13 Glasdam SM, Glasdam S, Peters GH. The importance of magnesium in the human body: A systematic literature review. Adv Clin Chem, 2016, 73: 169-193

14 Witte F, Kaese V, Haferkamp H, et al. In vivo corrosion of four magnesium alloys and the associated bone response. Biomaterials, 
2005, 26: 3557-3563

15 Witte F. Reprint of: The history of biodegradable magnesium implants: A review. Acta Biomater, 2015, 23: S28-S40

16 Li G, Zhang L, Wang L, et al. Dual modulation of bone formation and resorption with zoledronic acid-loaded biodegradable magnesium alloy implants improves osteoporotic fracture healing: An in vitro and in vivo study. Acta Biomater, 2018, 65: 486-500

$17 \mathrm{Wu} \mathrm{Y,} \mathrm{He} \mathrm{G,} \mathrm{Zhang} \mathrm{Y,} \mathrm{et} \mathrm{al.} \mathrm{Unique} \mathrm{antitumor} \mathrm{property} \mathrm{of} \mathrm{the} \mathrm{Mg-}$ Ca-Sr alloys with addition of Zn. Sci Rep, 2016, 6: 21736

18 Zhang Y, Ren L, Li M, et al. Preliminary study on cytotoxic effect of biodegradation of magnesium on cancer cells. J Mater Sci Tech, 2012, 28: 769-772

19 Chen Y, Xiao M, Zhao H, et al. On the antitumor properties of biomedical magnesium metal. J Mater Chem B, 2015, 3: 849-858

20 StJohn DH, Easton MA, Qian M, et al. Grain refinement of magnesium alloys: A review of recent research, theoretical developments, and their application. Metall Mat Trans A, 2013, 44: 2935-2949

21 Xia J, Chen H, Yan J, et al. High-purity magnesium staples suppress inflammatory response in rectal anastomoses. ACS Appl Mater Interfaces, 2017, 9: 9506-9515

22 Dole M, Wilson FR, Fife WP. Hyperbaric hydrogen therapy: A possible treatment for cancer. Science, 1975, 190: 152-154

23 Ishikawa $\mathrm{K}$, Takenaga $\mathrm{K}$, Akimoto $\mathrm{M}$, et al. ROS-generating mitochondrial DNA mutations can regulate tumor cell metastasis. Science, 2008, 320: 661-664

24 Wang J, Witte F, Xi T, et al. Recommendation for modifying current cytotoxicity testing standards for biodegradable magnesium-based materials. Acta Biomater, 2015, 21: 237-249

25 Yang $\mathrm{H}$, Zhang $\mathrm{Y}$, Zhou Z, et al. Snail-1 regulates VDR signaling and inhibits $1,25(\mathrm{OH})-\mathrm{D}_{3}$ action in osteosarcoma. Eur J Pharmacol, 2011, 670: 341-346

26 Yang $\mathrm{H}$, Zhang $\mathrm{Y}$, Zhou Z, et al. Transcription factor Snai1-1 induces osteosarcoma invasion and metastasis by inhibiting Ecadherin expression. Oncology Lett, 2014, 8: 193-197

27 Liu T, Yu J, Deng M, et al. CDK4/6-dependent activation of DUB3 regulates cancer metastasis through SNAIL1. Nat Commun, 2017, 8: 13923

28 Dominguez D, Montserrat-Sentis B, Virgos-Soler A, et al. Phosphorylation regulates the subcellular location and activity of the Snail transcriptional repressor. MCB, 2003, 23: 5078-5089

29 Han Y, Kuang Y, Xue X, et al. NLK, a novel target of miR-199a-3p, functions as a tumor suppressor in colorectal cancer. Biomed PharmacoTher, 2014, 68: 497-505

30 Wang N, Zhang CQ, He JH, et al. miR-21 down-regulation suppresses cell growth, invasion and induces cell apoptosis by targeting FASL, TIMP3, and RECK genes in esophageal carcinoma. Dig Dis Sci, 2013, 58: 1863-1870

31 Meng F, Glaser SS, Francis H, et al. Functional analysis of micro RNAs in human hepatocellular cancer stem cells. J Cellular Mol Med, 2012, 16: 160-173

32 Zhao D, Huang S, Lu F, et al. Vascularized bone grafting fixed by biodegradable magnesium screw for treating osteonecrosis of the femoral head. Biomaterials, 2016, 81: 84-92

33 Schmidt W, Behrens $\mathrm{P}$, Brandt-Wunderlich C, et al. In vitro performance investigation of bioresorbable scaffolds-standard tests for vascular stents and beyond. Cardiovascul Revasculariz Med, 2016, 17: 375-383

34 Sezer N, Evis Z, Kayhan SM, et al. Review of magnesium-based biomaterials and their applications. J Magnesium Alloys, 2018, 6:
23-43

35 Qiao S, Wang Y, Zan R, et al. Biodegradable mg implants suppress the growth of ovarian tumor. ACS Biomater Sci Eng, 2020, 6: 1755-1763

36 Yang N, Gong F, Cheng L, et al. Biodegradable magnesium alloy with eddy thermal effect for effective and accurate magnetic hyperthermia ablation of tumors. Natl Sci Rev, 2020

37 Ohsawa I, Ishikawa $\mathrm{M}$, Takahashi $\mathrm{K}$, et al. Hydrogen acts as a therapeutic antioxidant by selectively reducing cytotoxic oxygen radicals. Nat Med, 2007, 13: 688-694

38 Ma N, Chen Y M, Yang B C. Magnesium metal-A potential biomaterial with antibone cancer properties. J Biomed Mater Res, 2014, 102: 2644-2651

39 Zhang $\mathrm{X}, \mathrm{Zu} \mathrm{H}$, Zhao D, et al. Ion channel functional protein kinase TRPM7 regulates Mg ions to promote the osteoinduction of human osteoblast via PI3K pathway: In vitro simulation of the bone-repairing effect of $\mathrm{Mg}$-based alloy implant. Acta Biomater, 2017, 63: 369-382

40 Leidi M, Wolf F, Maier JAM. Magnesium and cancer: More questions than answers. 2011, http://europepmc.org/abstract/ MED/29920015

41 Schmitz C, Perraud AL, Johnson CO, et al. Regulation of vertebrate cellular $\mathrm{Mg}^{2+}$ homeostasis by TRPM7. Cell, 2003, 114: 191-200

42 Thiery JP. Epithelial-mesenchymal transitions in tumour progression. Nat Rev Cancer, 2002, 2: 442-454

43 Jung KH, Kim JK, Noh JH, et al. Targeted disruption of Nemo-like kinase inhibits tumor cell growth by simultaneous suppression of cyclin D1 and CDK2 in human hepatocellular carcinoma. J Cell Biochem, 2010, 110: 687-696

44 Zhou Q, Zheng X, Chen L, et al. Smad2/3/4 pathway contributes to TGF- $\beta$-induced miRNA-181b expression to promote gastric cancer metastasis by targeting TIMP3. Cell Physiol Biochem, 2016, 39: 453-466

45 Zhang A, Liu Y, Shen Y, et al. miR-21 modulates cell apoptosis by targeting multiple genes in renal cell carcinoma. Urology, 2011, 78: 474.e13

46 Kaufhold S, Bonavida B. Central role of snaill in the regulation of emt and resistance in cancer: A target for therapeutic intervention. J Exp Clin Cancer Res, 2014, 33: 62

47 Chen GC, Pang Z, Liu QF. Magnesium intake and risk of colorectal cancer: A meta-analysis of prospective studies. Eur J Clin Nutr, 2012, 66: 1182-1186

48 Skrajnowska D, Bobrowska-Korczak B. Role of zinc in immune system and anti-cancer defense mechanisms. Nutrients, 2019, 11: 2273

49 Costello LC, Franklin RB. Cytotoxic/tumor suppressor role of zinc for the treatment of cancer: An enigma and an opportunity. Expert Rev Anticancer Ther, 2012, 12: 121-128

50 Costa da Silva M, Breckwoldt MO, Vinchi F, et al. Iron induces anti-tumor activity in tumor-associated macrophages. Front Immunol, 2017, 8: 1479

Acknowledgements This work was supported by the National Key Research and Development Program of China (2018YFC1106600), and the Interdisciplinary Program of Shanghai Jiao Tong University (ZH2018QNB07).

Author contributions Zan R and Ji W designed the study and performed the cell experiments. Ni J, Wang $\mathrm{W}$ and Zhang $\mathrm{S}$ assisted in the animal experiment. Qiao S and $\mathrm{Wu} \mathrm{H}$ prepared the $\mathrm{Mg}$ material. Zhang 
$\mathrm{X}$ and Yang B analyzed the data. Song Y and Ji T revised the manuscript.

Conflict of interest The authors declare that they have no conflict of interest.

Supplementary information Experimental details and supporting data are available in the online version of the paper.

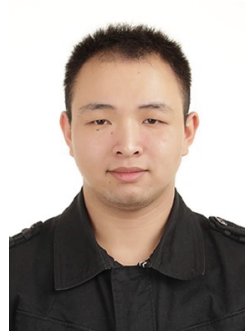

Rui Zan is a $\mathrm{PhD}$ candidate at the State Key Laboratory of Metal Matrix Composites, School of Materials Science and Engineering, Shanghai Jiao Tong University (SJTU). His research focuses on the effect of biodegradable $\mathrm{Mg}$ and its degradation products on tumor cells.

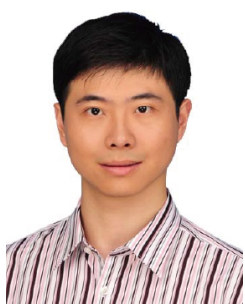

Weiping $\mathrm{Ji}$ is an MD and $\mathrm{PhD}$ in the Department of Orthopedic Surgery, Affiliated Sixth People's Hospital, SJTU, Shanghai, China. His research focuses on the clinical diagnosis and treatment of bone tumors and the design and development of orthopedic biomaterials as well.

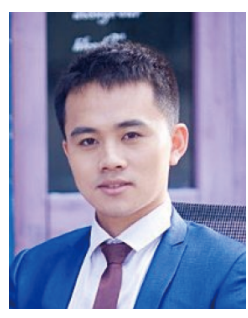

Yang Song is currently working as an associate professor at the School of Material Science and Engineering, SJTU. He received his $\mathrm{PhD}$ degree from the University of Hong Kong (2011-2015) and later worked as a postdoctoral fellow at the University of Michigan (2016-2017) and Georgia Tech (2017-2020). His research interests focus on the design of biomimetic materials for biomedical applications, including synthetic liquid organelles, DNA-based microwebs for immunotherapy, as well as implantable and degradable medical devices.

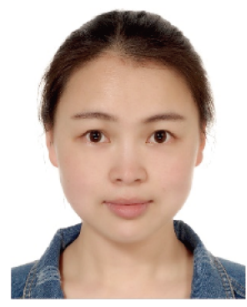

Jiahua Ni received her $\mathrm{PhD}$ degree from SJTU. She has been working as a postdoctoral fellow in Mechanical Engineering at Massachusetts Institute of Technology since 2019. Dr. Ni's current research interests include biodegradable magnesium medical devices and medical hydrogel.

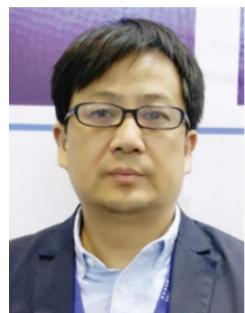

Xiaonong Zhang is currently working as an associate professor at the School of Material Science and Engineering, SJTU. He completed his $\mathrm{PhD}$ degree from SJTU and was a postdoctoral fellow in the Department of Materials, Queen Mary University of London. His current research interests are metal matrix composites and biodegradable metals and devices.

\section{生物可降解镁植入物一一骨肿瘤患者的潜在支架}

苜点 ${ }^{1 \dagger}$, 嵇伟平 ${ }^{2 \dagger}$, 乔爽 ${ }^{1}$, 吴宏流 ${ }^{1}$, 王文辉 ${ }^{1}$, 季天骄 ${ }^{3}$, 杨邦成 ${ }^{4}$,

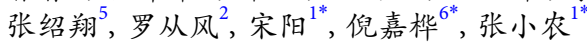

摘要 骨癌患者切除术后可能发生复发和转移. 传统的金属支架可 以对骨缺损部位提供力学支撑，但无法有效清除复发的肿瘤细胞. 本文中，我们介绍了一种可以抑制骨肉瘤生长的生物可降解镁丝 植入物. 简而言之, 镁丝释放镁离子激活锌指蛋白Snail1从胞浆到 细胞核的转运, 通过下游的miRNA-181d-5p/TIMP3 和miRNA181c-5p/NLK两条平行的抗肿瘤信号通路诱导骨肉瘤细胞凋亡, 抑 制骨肉瘤细胞增殖. 同时, 镁丝释放出的氢气消除了细胞内过多的 活性氧, 从而抑制了骨肿瘤细胞的生长. 裸鼠骨肉瘤细胞皮下荷瘤 实验进一步证实镁丝能有效抑制肿瘤生长, 延长荷瘤小鼠生存期. 此外, 镁丝对正常细胞和组织无毒性, 揭示了镁植入物是骨肉瘤患 者潜在的抗肿瘤支架材料. 